32 Trivedi MH, Rush AJ, Crismon ML, Kashner TM, Toprac MG, Carmody TJ, et al. Clinical results for patients with major depressive disorder in the Texas Medication Algorithm Project. Arch Gen Psychiatry 2004; 61: 669-80.

33 Weinmann S, Hoerger S, Erath M, Kilian R, Gaebel W, Becker T. Implementation of a schizophrenia practice guideline: clinical results. J Clin Psychiatry 2008; 69: 1299-306.

34 Yoshino A. Algorithm-guided treatment versus treatment as usual for major depression. Psychiatry Clin Neurosci 2009; 5: 652-7.

35 Karbach U, Schubert I, Hagemeister J, Ernstmann N, Pfaff H, Höpp H. Physicians' knowledge of and compliance with guidelines: an exploratory study in cardiovascular diseases. Dtsch Arztebl Int 2011; 108: 61-9.

36 Hagemeister J, Schneider CA, Diedrichs H, Mebus D, Pfaff H, Wassmer G, et al. Inefficacy of different strategies to improve guideline awareness
- 5-year follow-up of the hypertension evaluation project (HEP). Trials 2008; 9: 39

37 Hagemeister J, Schneider CA, Barabas S, Schadt R, Wassmer G, Mager G, et al. Hypertension guidelines and their limitations - the impact of physicians' compliance as evaluated by guideline awareness. J Hypertension 2001; 19: 2079-86.

38 Rothwell PM. External validity of randomised controlled trials: "to whom do the results of this trial apply?". Lancet 2005; 365: 82-93.

39 Perlis RH. Use of treatment guidelines in clinical decision making in bipolar disorder: a pilot survey of clinicians. Curr Med Res Opin 2007; 23: $467-75$

\title{
Camus and modern psychiatry: The Myth of Sisyphus
}

\section{Thom Proven}

Albert Camus (1913-1960), aside his onetime great ally Sartre, was an important post-war French existential philosopher, although he later rejected that label. He was French-Algerian and spent his early years in North Africa, later moving to France and playing an active role in the French Resistance during the Second World War. He went on to establish himself in the Parisian intellectual leftbank scene before dying in a car crash in 1960. An unused train ticket for the same journey was found in his coat pocket having changed his travel plans last minute.

Camus did not shy away from tackling the big issues of life head on: 'There is only one really serious philosophical problem, and that is suicide. Deciding whether or not life is worth living is to answer the fundamental question in philosophy. All other questions follow from that'. These are the opening lines of his 1942 essay The Myth of Sisyphus, where he seeks to further the themes of 'the absurd' explored in the classic The Outsider. His thesis is that given that life will, without exception, end, what is the point? Man searches for reason, meaning and order, only to march irreconcilably towards his own demise. Surely everything we do is absurd, and once resigned (or enlightened) to this decision examples of this absurdity can be seen everywhere.

The question that Camus addresses is how can we find meaning in a meaningless world? Philosophers before him had sought this meaning from a higher source, a greater power, from God. Camus however would reject this conclusion, feeling it to be a contradiction of the absurd, and hence not a reconciliation - 'philosophical suicide'. Camus would extend the same argument to suicide. He views it as a 'not legitimate' choice, a side step away from dealing with the paradox presented by an absurd world (human striving for meaning in a meaningless world); without man, the absurd cannot exist.

So what's left? How can we live a satisfactory life whilst at the same time accepting the absurdity of our condition? Camus suggests giving oneself over to the absurd, revelling in it, enjoying the tension that it creates and living in the moment. He suggests finding meaning by becoming, to quote from Introducing Camus (Mairowitz \& Korkos, Icon Books, 2007): 'a great sensualist for whom sun, sea, sex, football, and theatre were the answer to life's absurdity'.

Camus finished the essay with the story of Sisyphus - the king of Ephyra punished by the gods for believing himself above their power to roll a great boulder up a mountain each day, only to watch it roll back to the base after his day of toil. He is interested however, in Sisyphus' return journey down the mountain where he is faced with his wretched condition: 'The lucidity that was to constitute his torture at the same time crowns his victory. There is no fate that cannot be surmounted by scorn', writes Camus before concluding (with a nod to the words of Oedipus) 'all is well . . . One must imagine Sisyphus happy'.

What is the relevance of this to the practice of psychiatry today? Should we be guiding our patients towards a celebration of the absurdity of existence when they struggle to see a meaning? Maybe there is a message to take from this, that there are small glimmers of meaning in a patient's life to hold on to and it should be a priority to identify these? Maybe we should view treatments as merely adjuncts to improve the patient's ability to find meaning in life rather than a cure? Maybe as a profession we should be more keenly aware of absurdity in our own actions? 